\title{
PENERAPAN TEKNOLOGI ONLINE MONITORING KUALITAS AIR UNTUK DAS PRIORITAS DI SUNGAI CILIWUNG DAN SUNGAI CISADANE
}

\author{
Application of Online Water Quality Monitoring Technology for Priority Basin \\ in Ciliwung River and Cisadane River \\ Oleh: \\ Heru Dwi Wahjono \\ Pusat Teknologi Lingkungan, BPPT
}

\begin{abstract}
Abstrak
Sungai Ciliwung dan Sungai Cisadane merupakan dua sungai induk dari salah satu DAS Prioritas yang telah ditetapkan oleh pemerintah Indonesia. Penetapan ini didasari salah satunya adalah oleh perlunya pengelolaan sumberdaya air di DAS Ciliwung-Casadane ini yang sudah semakin rusak. Kementerian Lingkungan Hidup dan Kehutanan (KLHK) menjadikan DAS Ciliwung-Cisadane salah satu target pengendalian pencemaran melalui kegiatan penerapan teknologi online monitoring kualitas air. Teknologi online monitoring ini diperlukan untuk mendapatkan data pemantauan secara kontinyu untuk membuktikan terjadinya tindak pencemaran oleh industri yang ada di wilayah DAS ini. Sistem yang diterapkan adalah sistem pemantauan kualitas air online dan realtime yang berbasis GSM. Dalam tulisan ini akan dibahas mengenai proses instalasi, hasil pemantauan, dan kendala yang dihadapi.
\end{abstract}

Kata Kunci : DAS prioritas, DAS Clliwung-Clsadane, teknologi online monitoring, online dan realtime data.

\begin{abstract}
Ciliwung and Cisadane are two main river from one of the priorities water shed set by the Indonesian government. This determination is based on one of which was the need for water resource management in Ciliwung-Casadane is already getting damaged. Ministry of Environment and Forests (KLHK) makes Ciliwung-Cisadane one of the targets of pollution control through the application of online monitoring technology for quality water. This online monitoring technology is required to obtain a continuous monitoring data to prove the pollution by industries in this watershed area. The system applied is an online and realtime water quality monitoring system based on GSM technology. In this paper will discuss the installation process, the monitoring results, and the obstacles encountered.
\end{abstract}

Keywords: Priorities watershed, Ciliwung-Casadane Watershed, online monitoring technology, online and realtime data.

\section{PENDAHULUAN}

\subsection{Latar Belakang}

Pertumbuhan penduduk yang pesat di kotakota besar dan sekitarnya maupun di wilayah Daerah Aliran Sungai (DAS) Ciliwung-Cisadane dapat membawa dampak kepada pencemaran perairan sungai yang cukup besar. Sumber pencemar berasal dari buangan limbah domestik dan industri yang ada di wilayah DAS tersebut. Selain itu pula peruntukan sungai dan fungsi sungai telah bergeser dari kondisi semula, ditandai dengan banyaknya bangunan ataupun tanggul-tanggul beton pada sepadan sungai. Akibatnya sungai menjadi tercemar dan tidak sehat.
Saat ini dari 53 sungai di Indonesia, sebesar $73 \%$ di antaranya telah tercemar (Tempo.CO, 2015). Untuk itu demi menjaga keseimbangan ekosistem di DAS ini, perlu dilakukan restorasi sungai dan pemantauan kualitas air di sungai-sungai di DAS tersebut.

Berkaitan dengan kegiatan pengendalian pencemaran kualitas air di Sungai Ciliwung dan Sungai Cisadane pada Daerah Aliran Sungai CiliwungClsadane, telah dilaksanakan beberapa kegiatan pemantauan di sungai-sungai induk ini. Salah satunya adalah kegiatan pemantauan tinggi muka air untuk pengendalian banjir yang terjadi saat musim hujan dan kegiatan pemantauan kualitas air yang dilakukan beberapa kali dalam satu tahun. Sebagai contoh 
Pemda DKI Jakarta telah memantau kualitas air sungai Ciliwung yang memiliki aliran sepanjang hampir 120 km yang melewati Jakarta, Tangerang, Bogor, dan Depok dengan daerah tangkapan air seluas $387 \mathrm{~km}^{2}$ serta Kota Tangerang dan Bogor telah melaksanakan pemantauan kualitas air Sungai Cisadane sepanjang $126 \mathrm{~km}$ secara rutin (Wikipedia, 2016).

Kegiatan pemantauan kualitas air sangat dibutuhkan dalam kegiatan restorasi sungai. Faktor utama yang menjadikan berhasil tidaknya restorasi sungai, adalah pengendalian pencemaran air yang masuk ke lokasi sungai yang akan direstorasi. Upaya untuk mengendalikan pencemaran, salah satunya adalah pemantauan kualitas air baik yang akan masuk ke sungai, atau di lokasi aliran sungai. Pemantauan ini perlu dilakukan secara terus menerus dengan cara menganalisis kualitas air yang masuk atau yang berada pada aliran sungai secara periodik. Bila ada polutan yang masuk ke sungai atau kondisi sungai tercemar ekstrim dalam suatu waktu tertentu, pemerintah atau pihak yang berwenang untuk mengelola sungai dapat melakukan tindakan tanggap pencemaran.

Untuk melakukan pemantauan kualitas air sungai, cara konvensional yang saat ini dilakukan adalah mengambil sampel di lokasi pemantauan, membawa ke laboratorium dan menganalisakannya. Banyak sekali kendala yang dihadapi terkait pemantauan rutin kualitas air sungai secara konvensional ini, diantaranya adalah jarak dari lokasi ke laboratorium analisa kualitas air yang cukup jauh, kemacetan lalu litas, dan juga resiko bahaya saat pengambilan sampel langsung di lokasi sungai. Kendala lain yang cukup signifikan yakni biaya analisa sampel yang cukup mahal sehingga untuk melakukan pemantauan rutin di banyak titik di aliran sungai, anggaran yang diperlukan sangat besar.

Kendala yang sama juga dialami oleh badan lingkungan hidup daerah (BLHD) Jawa Barat yang melaksanakan kegiatan pemantauan kualitas air di sepanjang Sungai Citarum. Selain air limbah domestik yang berkontribusi dalam pencemaran di sungaisungai besar ini, juga air limbah yang berasal dari industri kecil dan besar yang berada di sepanjang Sungai Cisadane. Pemantauan kualitas air manual yang selama ini dilaksanakan tidak mampu memberikan peringatan dini untuk terjadinya bencana pencemaran kualitas air. Untuk itu diperlukan alternaif teknologi pemantauan kualitas air yang mendukung kegiatan pengendalian pencemaran air.

Upaya yang perlu dilakukan untuk mengatasi kendala-kendala tersebut di atas dan mengefisienkan kegiatan pemantauan kualitas air, adalah dengan menerapkan sistem online monitoring kualitas air di beberapa lokasi pemantauan baik di lokasi sumber pencemar, maupun di lokasi aliran sungai itu sendiri. Dalam kerjasama kegiatan penerapan teknologi online monitoring kualitas air antara Kementerian Lingkungan Hidup dan Kehutanan (KLHK) dan Badan Pengkajian dan Penerapan Teknologi (BPPT) telah dihasilkan rekomendasi pemasangan peralatan online monitoring kualitas air di 15 DAS Prioritas di Indonesia secara bertahap seperti gambar di bawah ini.

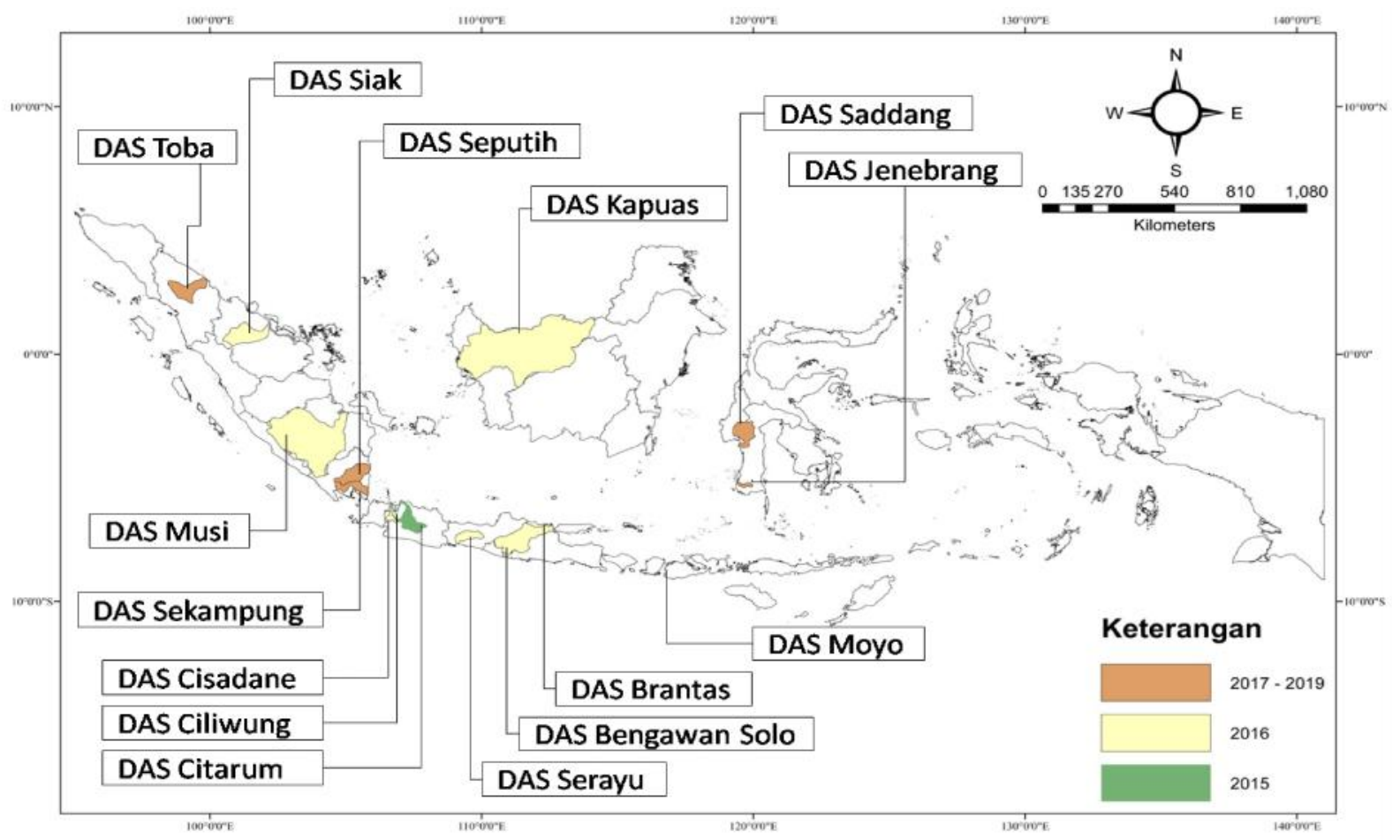

Gambar 1 : Peta Rencana Pemantauan Online Monitoring Kualitas Air di DAS Prioritas. 
Berbagai teknik dan metode sudah banyak dikembangkan dan diterapkan di beberapa daerah di Indonesia. Oleh karena itu kerjasama antara KLHK dan BPPT dalam penerapan teknologi online monitoring kualitas air diharapkan dapat memberikan solusi bagi kegiatan pengendalian pencemaran dan kerusakan kualitas lingkungan. Berbagai inovasi perlu dilakukan sesuai kebutuhan di lapangan dan karakteristik di kedua sungai di Sungai Ciliwung dan Sungai Cisadane. Pada stasiun monitoring di lokasi terdapat peralatan sistem pengambilan sampling, sistem solar cell dan panel kontrol sistem pompa serta sistem data logger dan transmisi data.

\subsection{Tujuan Dan Sasaran}

Tujuan dari kegiatan adalah merancang dan menerapkan teknologi online monitoring kualitas air di sungai Ciliwung dan sungai Citarum. Adapun sasarannya adalah tersedianya rancangan bangunan pelindung, sistem telemetri, jangka waktu kalibrasi sensor yang disesuaikan kondisi masing-masing sungai, kendala yang dihadapi, kehandalan sistem, dan upaya untuk meningkatkan kinerja sistem.

\section{METODOLOGI}

Metodologi pelaksanaan kegiatan yang akan digunakan untuk penerapan teknologi online monitoring kualitas air ini adalah berikut :

- $\quad$ Survei lokasi bertujuan untuk memilih lokasi yang cocok untuk pemasangan sistem telemetri dengan memperhatikan kriteria keamanan, kemudahan dalam pemasangan, dan pengelolaannya.

- Perancangan sistem dan peralatan meliputi perancangan sistem pengambilan sampling, bangunan pelindung dan mekanisme sistem pemompaan.

- Perakitan peralatan terdiri dari perakitan data logger, sistem solar cell, sistem kontrol pompa, dan sistem perpipaan untuk pengambilan sampling air.

- Instalasi peralatan dilakukan dengan memasang seluruh sistem sensor dan telemetri pada titik lokasi yang telah ditentukan.

- Pengoperasian dan pengamatan di pusat data dilakukan dengan mengoperasikan software SMS gateway untuk mengendalikan data logger, software database online monitoring dan aplikasi berbasis web.

\section{HASIL DAN PEMBAHASAN}

\subsection{Sistem Telemetri Berbasis Teknologi GSM}

Pemantauan yang dilaksanakan di remote area seperti yang dilaksanakan di Sungai Ciliwung dan di
Sungai Cisadane membutuhkan teknologi telemetri dengan pilihan teknologi komunikasi data jarak jauh. Beberapa pilihan teknologi komunikasi yang ada di antaranya adalah teknologi komunikasi radio, teknologi komunikasi satelit, dan teknologi komunikasi GSM.

Dari ketiga teknologi komunikasi ini teknologi GSM layak digunakan dalam penerapan teknologi online monitoring kualitas air di lokasi remote area dengan beberapa keuntungan, yaitu :

- Tidak memerlukan investasi infrastruktur jaringan

- Jaringan komunikasi sudah tersebar hampir di seluruh pelosok di Nusantara

- Biaya sewa dan pengoperasiannya murah dan terdapat berapa jenis produk layanan

- Mudah penggunaannya dan sudah umum digunakan oleh masyarakat dan industri

Selain beberapa keuntungan yang didapat dari penggunaan teknologi komunikasi GSM, beberapa kekurangan dari penggunaan teknologi ini untuk keperluan telemetri adalah sebagai berikut :

- Sangat tergantung dengan cakupan area jaringan GSM. Wilayah yang tidak tercakup tidak bisa menggunakan teknologi ini.

- Masih menggunakan infrastruktur jaringan komunikasi publik sehingga kualitas komunikasi sangat dipengaruhi dengan penggunannya oleh publik.

- Konfigurasi sistem komunikasi tidak bisa dimodifikasi tanpa melibatkan operator jaringan.

Hasil survei kekuatan sinyal GSM pada pemilihan lokasi di lapangan menunjukan lokasi-lokasi pemantauan yang dipilih memiliki kekuatannya sinya minimal 3G, sehingga cukup baik untuk digunakan sebagai jaringan komunikasi pengiriman data dari masing-masing lokasi pemantauan ke pusat data.

\subsection{Lokasi Pemasangan Peralatan}

Penentuan lokasi dilakukan melalui survei yang dilaksanakan bersama-sama tim BPPT, KLHK dan BBWSCC. Lokasi yang dipilih harus memenuhi kriteria sebagai berikut (Heru Dwi Wahjono, dkk, 2015) :

- Memiliki sinyal GSM dari salah satu operator seluler yang kuat di level HSPA dan minimal GPRS.

- Akses menuju lokasi tersebut mudah dan jarang dilewati kendaraan.

- Lokasi tersebut milik instansi pemerintah agar mudah untuk memperoleh izin pembangunan bangunan pelindung dan pemasangan peralatan telemetrinya.

- Lokasi tersebut memiliki keamanan yang baik dan tidak mudah diakses oleh orang yang tidak berkepentingan. 
Lokasi yang sudah ditetapkan dari hasil survei untuk pemasangan di Sungai Ciliwung dan Sungai Cisadane adalah sebagai berikut :

1. Lokasi Masjid Isqitlal yang berada di dalam halaman Masjid Isqitlal di kecamatan Pasar Baru, Jakarta Pusat, dengan posisi koordinat (-6.17140, 106.83103). Lokasi intake merupakan bagian hilir Sungai Ciliwung yang mewakili area domestik perkantoran.

2. Lokasi Manggarai yang berada di dalam halaman pintu air Manggarai dengan posisi koordinat (6.20784, 106.84850). Lokasi intake merupakan bagian hilir Sungai Ciliwung yang mewakili area domestik pemukiman padat.

3. Lokasi Kelapa Dua, di alamat Kelurahan Srengseng Sawah, Depok dengan posisi koordinat (-6.35264, 106.83564) Lokasi intake merupakan bagian tengah sedikit ke hulu Sungai Ciliwung yang mewakili area domestik pemukiman.

4. Lokasi Bendung Empang, di alamat Kampung Pulo, Kelurahan Pawedang, Kec Bogor Tengah dengan posisi koordinat $(-6.60777,106.79288)$. Lokasi intake merupakan bagian hulu Sungai Cisadane yang mewakili area domestik pemukiman.

5. Lokasi Bendung Pasar Baru, di alamat Kelurahan Koang Jaya - Kecamatan Karawaci Kota Tangerang dengan posisi koordinat (-6.16079, 106.62772). Lokasi intake merupakan bagian hilir Sungai Cisadane yang mewakili area area industri.

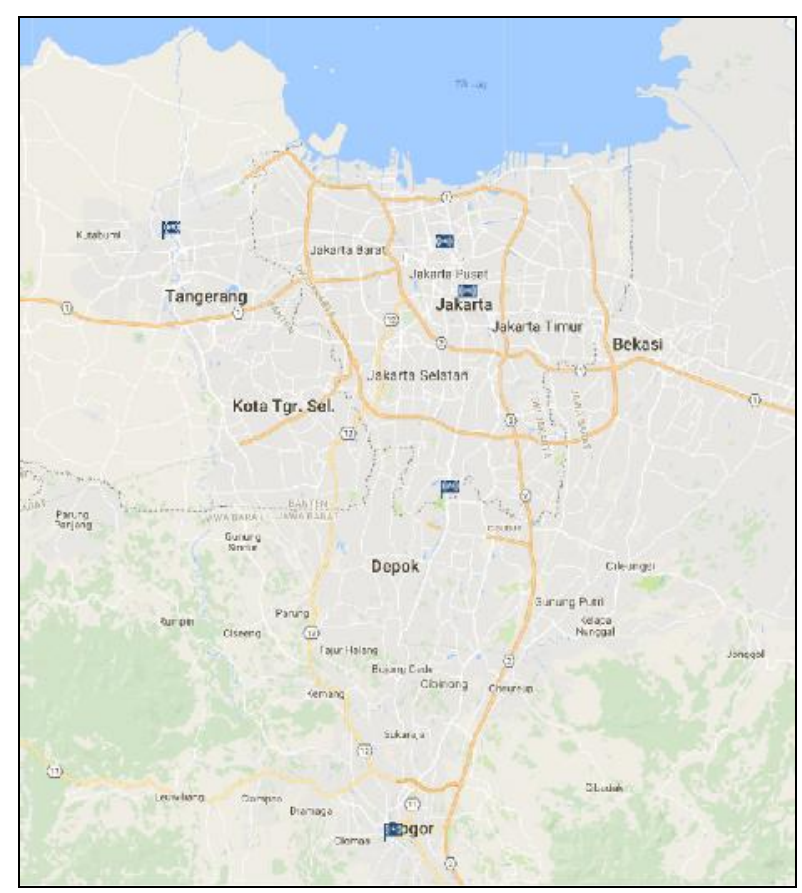

Gambar 2 : Peta Lokasi Stasiun Pemasangan Peralatan.

\subsection{Hardware Remote Terminal Unit (RTU)}

Sistem telemetri berbasis teknologi GSM terdiri dari hardware remote terminal unit (RTU) dan hardware/software data center. Hardware RTU merupakan sistem peralatan yang ditempatkan di lokasi pemantauan di Sungai. RTU terdiri dari perangkat smart data logger, digital multiprobe sensor, sistem kelistrikan solar cell dan sistem pengambilan sampling yang terintegrasi.

Perangkat smart data logger merupakan sistem komputer yang mengendalikan proses pengambilan sampling, pengecekan data dan pengiriman data ke data center. Data logger memiliki beberapa fitur utama, yaitu pengiriman data berbasis SMS dan dapat lebih dari 164 karakter, memiliki dua jenis interval pemantauan (periodik dan EWS/early warning system) yang dapat disetting dan dimonitoring dari pusat data, delay waktu pengukuran kualitas untuk EWS hanya 60 detik, status memori dan status pengiriman data dapat dimonitoring dari pusat data, serta memiliki onsite display untuk menampilkan hasil pengukuran setiap saat di lapangan. Spesifikasi teknis lainnya adalah sebagai berikut (Bayu Budiman dan Heru Dwi Wahjono, 2013).

- Serial RS-232 port : 1 main, 3 slave

- 8 channel analog port

- 8 bit optocoupler TTL input, extendable to 40 bit

- 4 bit Transistor output, extendable to 20 bit

- 256 kByte flash memori

- Real Time Clock dan

- Dilengkapi PLC untuk EWS

Gambar berikut ini menunjukkan perangkat smart data logger untuk system telemetri.

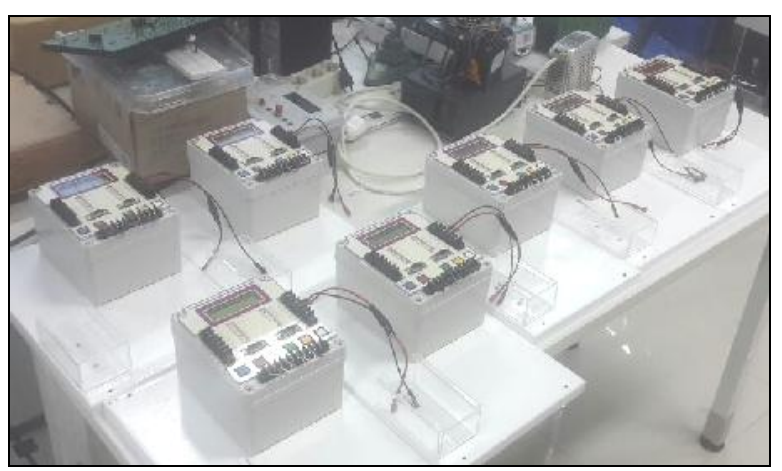

Gambar 3 : Smart Data Logger

Digital multiprobe sensor merupakan perangkat yang akan melakukan pengukuran 12 parameter kualitas air sekaligus secara bersamaan, yaitu : Temperatur, Conductivity, TDS, Salinity, DO, pH, Turbidity, Depth, SwSG, Ammonium, Nitrate, ORP. Melalui perangkat handheld multiprobe sensor terhubung dengan smart data logger melalui koneksi serial RS232. Gambar berikut merupakan sensor multiprobe DKK-TOA tipe WQC-24. (TOA-DKK, 2015). 
Perangkat lainnya yang masuk ke dalam hardware RTU adalah sistem kelistrikan dengan solar cell. Perangkat yang dibutuhkan menggunakan kapasitas panel surya $50 \mathrm{Wp}$ dengan tegangan kerja 12 volt. Battery atau aki kering untuk penyimpanan yang digunakan adalah berkapasitas 12 Ah dengan tegangan kerja 12 volt. Dengan spesifikasi tersebut diharapkan mampu memenuhi sumber kelistrikan bagi perangkat RTU selama 24 jam.

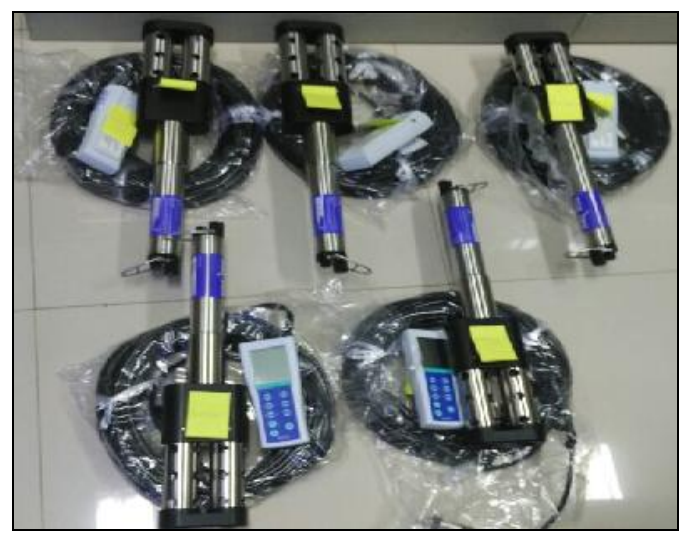

Gambar 4 : Sensor WQC-24

\subsection{Sistem Pengambilan Sampling}

Sistem pengambilan sampling di lokasi pemantauan di Sungai Ciliwung dan Cisadane terdiri dari dua jenis sistem pengambilan sampling, yaitu (BPPT Enjiniring, 2015) :

(1). Pencelupan sensor secara langsung ke sungai.

Pada sistem pencelupan langsung ke sungai, sensor dicelupkan secara langsung ke dalam sungai melalui pipa pelindung / casing yang terbuat dari bahan PVC yang telah diberi lubang agar air dalam pipa dapat masuk dan mengalir. Agar dapat mengikuti tinggi muka air sungai, sensor diberi pelampung yang juga terbuat dari bahan PVC sehingga dapat naik turun mengikuti permukaan air. Sistem ini diterapkan di lokasi Bendung Empang (foto atas) dan Bendung Pasar Baru (foto bawah) seperti gambar di berikut ini.

(2.) Penggunaan sistem pompa.

Pada sistem pompa, sensor dicelupkan ke dalam tangki yang berisi air sungai yang secara otomatis air sungai dalam tangki tersebut dapat berganti secara rutin dengan menggunakan pompa air. Pompa dapat menyala sesuai internval waktu dan lama pemompaan sesuai yang dibutuhkan. Untuk itu diperlukan sistem timer pompa tersendiri yang diintegrasikan dengan sistem smart data logger. Skema timer pompa ada pada lampiran. Sistem ini diterapkan di lokasi masjid Istiqlal, Manggarai, dan Kelapa Dua. Gambar berikut ini adalah pipa intake (atas) dan sistem pemompaan di dalam bangunan pelindung.

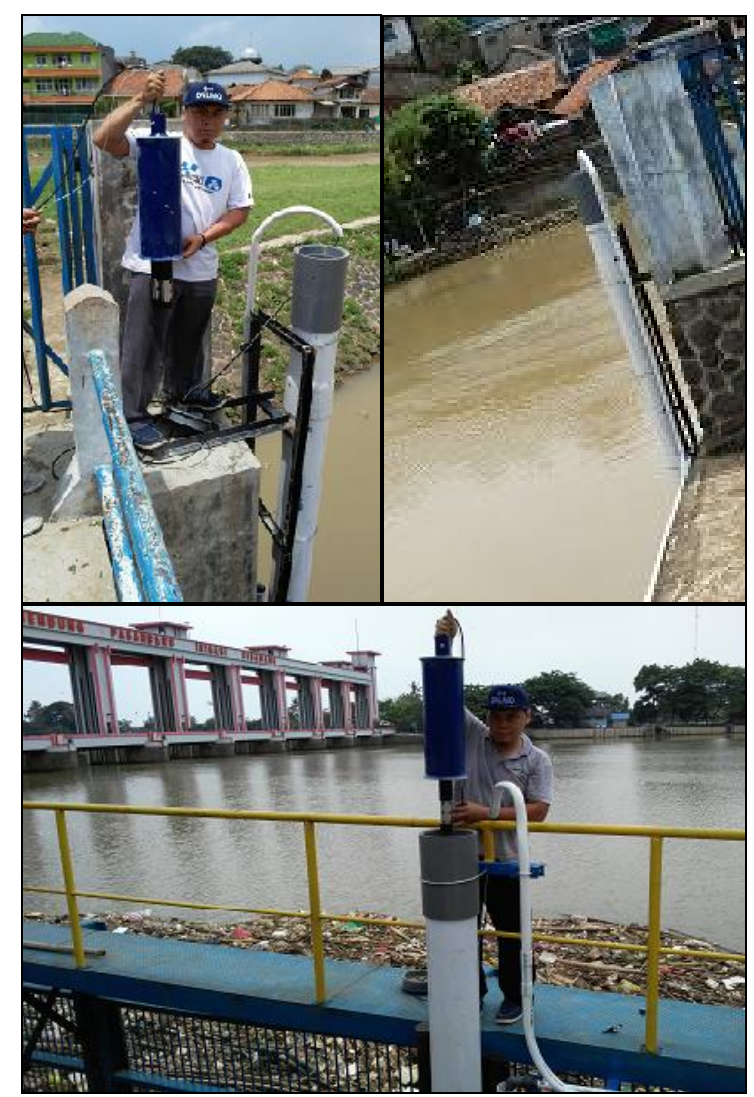

Gambar 5 : Sistem Pencelupan Sensor Secara Langsung

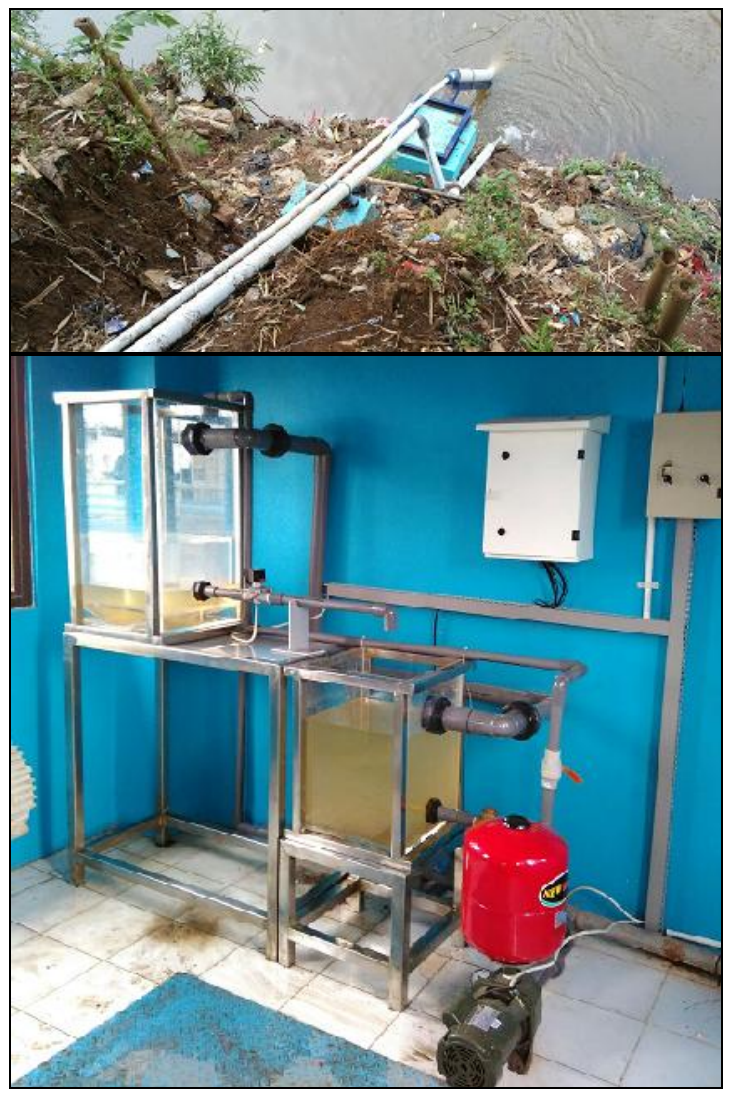

Gambar 6 : Pipa Intake dan Sistem Pemompaan 


\subsection{Bangunan Pelindung}

Aliran air di Sungai Ciliwung dan Cisadane termasuk dalam kategori sedang dan tinggi, oleh karena itu pemasangan peralatan sistem telemetri di kedua sungai ini membutuhkan bangunan pelindung berupa bangunan sipil beton. Bangunan pelindung berfungsi untuk menempatkan semua peralatan RTU dan sistem pemompaan. Bangunan pelindung yang dibuat di lokasi kedua sungai ini memiliki spesifikasi teknis sebagai berikut (BPPT Enjiniring, 2015) :

- Panjang $x$ Lebar $\times$ Tinggi $=200 \times 150 \times 300 \mathrm{~m}$

- Pondasi $=60 \times 40 \mathrm{~cm}$

- Sloop $=15 \times 15 \mathrm{~cm}$

- Dinding bata, plester, aci

- Lantai keramik

- Atap cor beton

Gambar berikut ini adalah sketsa bangunan pelindung untuk kelima lokasi stasiun pemantauan di lokasi Sungai Ciliwung dan Sungai Cisadane. Foto untuk masing-masing lokasi ada pada lampiran gambar $24 \sim$ gambar 27.

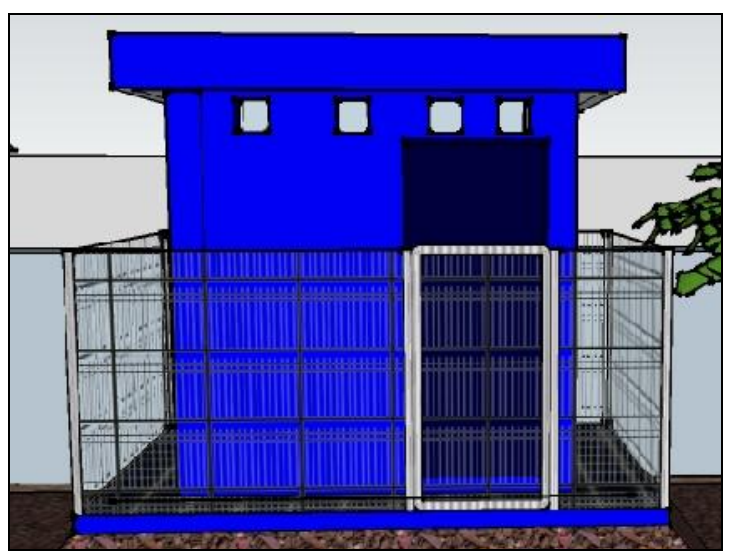

Gambar 7 : Sketsa Bangunan Pelindung

\subsection{Pusat Data Online Monitoring}

Pusat data online monitoring diperlukan untuk penerimaan data pemantauan dari masing-masing lokasi pemantauan. Komponen pusat data terdiri dari sebuah komputer yang dioperasikan sebagai server penerima data, perangkat GSM modem dan software online monitoring yang terdiri dari aplikasi SMS gateway, aplikasi database untuk pengelolaan data dan aplikasi web untuk publikasi ke internet.

Spesifikasi minimal perangkat komputer yang dioperasikan sebagai server penerima data adalah sebagai berikut (Heru Dwi Wahjono, 2013) :

- Processor Pentium IV

- Memori 512 MB, Cache 512 KB, VGA 64 MB

- Monitor 17", Min. Resolusi 2048 x 1024

- Media Backup CD-ROM Writer

- Printer Color A4 Printer
Gambar berikut adalah perangkat komputer server pada pusat data dengan aplikasi online monitoring kualitas air yang sedang beroperasi. Diperlukan dua layar monitor untuk menampilkan dua jenis aplikasi yang berbeda secara bersamaan.

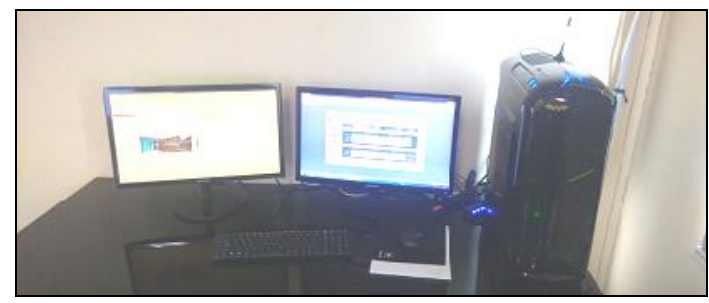

Gambar 8 : Komputer Server Penerima Data

Spesifikasi teknis perangkat lunak SMS gateway yang digunakan adalah (Heru Dwi Wahjono, dkk, 2015) :

- Multi station monitoring.

- Remote control memakai SMS \& perintah AT.

- Peringatan dini atau Early Warning System.

- Nilai baku mutu kualitas air dapat diset.

- Multi user SMS dan EWS.

- Interval waktu pengukuran dapat diset.

- Interval waktu pengiriman data dapat diset.

- Data record dalam format txt (pipe delimited).

- Terdapat informasi status battery, memori dan sisa pulsa untuk kartu prabayar.

- Terdapat fungsi peringatan dini berupa red blink. Gambar di bawah ini adalah tampilan aplikasi SMS gateway yang menampilkan status pemantauan pada stasiun onlimo Manggarai.

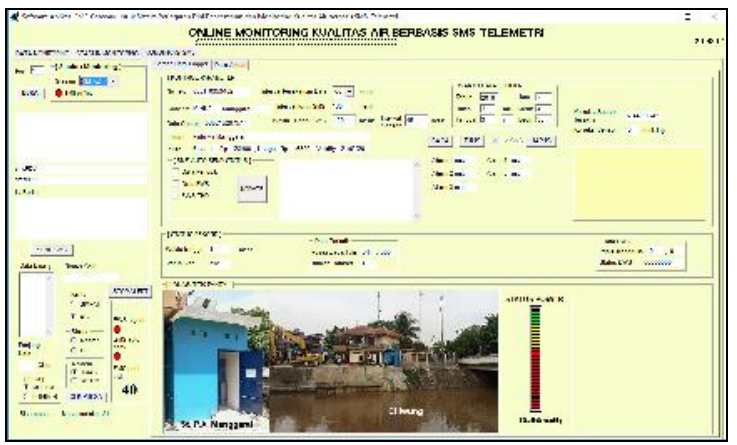

Gambar 9 : Aplikasi SMS Gateway

Spesifikasi teknis aplikasi database online monitoring kualitas air yang digunakan adalah (Heru Dwi Wahjono, dkk, 2015) :

- Mengelola data stasiun dan data kualitas air.

- Penggunaan bersama file oleh aplikasi SMS Gateway melalui file data dalam format teks.

- Memantau data secara online dan realtime.

- Menampilkan data pengukuran dalam bentuk angka dan grafik analisa.

- Tersedia laporan ringkas, detail dan lengkap. 
- Tersedia dokumen elektronik untuk online manual, regulasi dan data baku mutu.

- Penelusuran data : harian / bulanan / stasiun Gambar 10 berikut ini adalah tampilan aplikasi database online monitoring yang dapat digunakan untuk pengelolaan data pemantauan kualitas air.

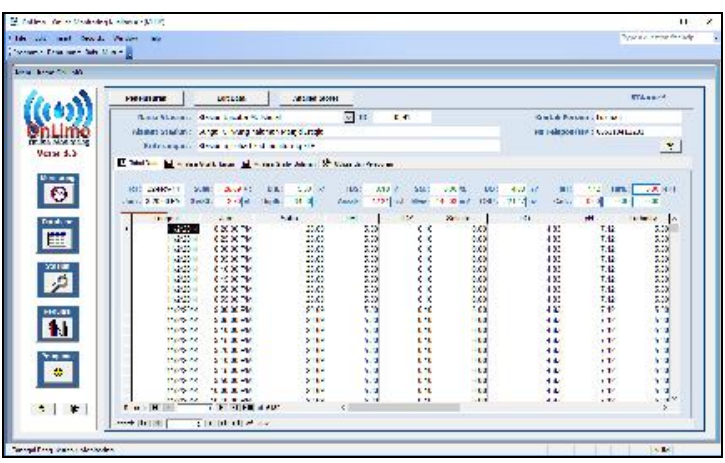

Gambar 10 : Aplikasi Database Online Monitoring

Spesifikasi teknis aplikasi web yang digunakan adalah (Heru Dwi Wahjono, dkk, 2015) :

- Format database MySQL dengan sistem administrasi database.

- Mengelola data multi stasiun dan multi data monitoring.

- Dapat memonitoring data secara online dan realtime serta visual.

- Dapat menampilkan data dalam bentuk angka dan analisa grafik perjam, harian dan bulanan.

- Laporan ringkas, rinci, dan lengkap.

- Memliki informasi baku mutu, regulasi, berita iptek, dan artikel ilmiah.

- Penelusuran data harian/bulanan per stasiun.

- Peta untuk navigasi lokasi stasiun dan data pemantauan.
Gambar 11 di bawah ini adalah tampilan aplikasi web yang dapat digunakan pengguna internet untuk menelusuri data pemantauan kualitas air.

\subsection{Hasil Pemantauan Kualitas Air}

Untuk mengindentifikasikan masing-masing lokasi pemantauan, maka ditetapkan nomor identifikasi stasiun pemantuan, yaitu :

- KLHK1 adalah Nomor ID Stasiun untuk lokasi Masjid Istiqlal yang berada Jakarta Pusat mewakili bagian hilir Sungai Ciliwung.

- KLHK2 adalah Nomor ID Stasiun untuk lokasi Manggarai yang berada di Jakarta Selatan mewakili bagian tengah Sungai Ciliwung.

- KLHK4 adalah Nomor ID Stasiun untuk lokasi Kelapa Dua yang berada di Serengseng Depok mewakili bagian hulu Sungai Ciliwung.

- KLHK5 adalah Nomor ID Stasiun untuk lokasi Bendung Empang yang berada di Kota Bogor mewakili bagian hulu Sungai Cisadane.

- KLHK6 adalah Nomor ID Stasiun untuk lokasi Bendung Pasar Baru yang berada di Kota Tangerang mewakili bagian hilir Sungai Cisadane.

Hasil pemantauan kualitas air untuk kelima lokasi tersebut di atas selanjutnya dapat ditelusuri menggunakan nomor identifikasi stasiun (IDStasiun) tersebut melalui aplikasi database atau aplikasi web online monitoring kualitas air. Kelima stasiun pantau melalukan pengukuran kualitas air setiap 1 jam sekali dan mengirimkan datanya ke pusat data setiap 3 jam sekali.

Data dari setiap stasiun pantau teridentifikasi sesuai primary key yang telah ditetapkan dalam sistem database, yakni :

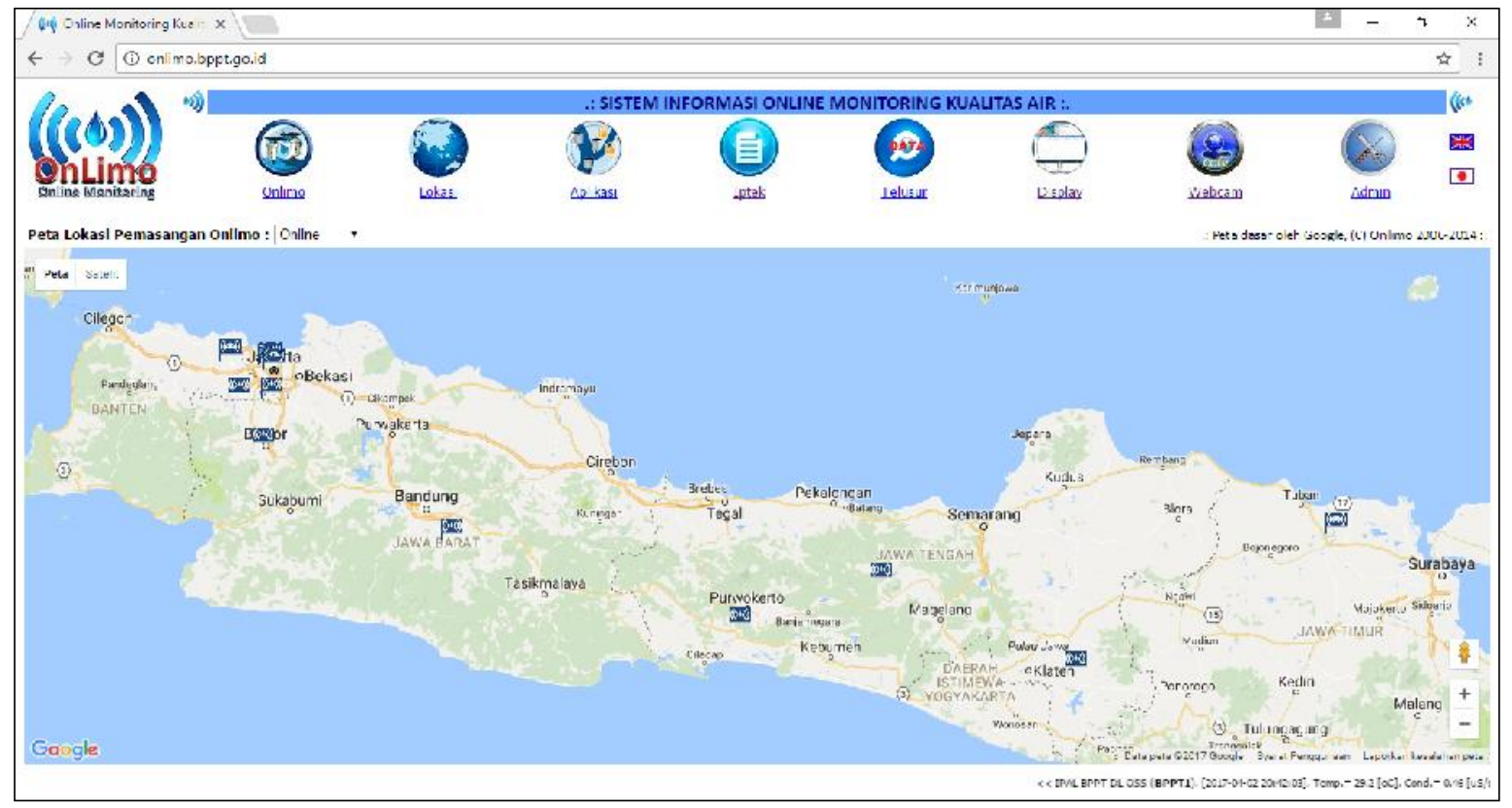

Gambar 11 : Aplikasi Web Online Monitoring 


\section{IDStasiun | Tanggal (DD-MM-YYYY) | Jam (HH:MM:SS)}

Selanjutnya data hasil pengukuran setiap parameter nya akan tersusun dalam database dengan urutan sebagai berikut :

\section{| Suhu | DHL | TDS | Salinitas | DO | PH | Turbidity | SwSG | Amonia | Nitrat | ORP |}

Berikut ini adalah contoh data kelima stasiun yang masuk dalam file database. Data pengukuran dari kelima stasiun pantau di Sungai Ciliwung dan Sungai Cisadane tersimpan ke dalam database setiap jam nya yang dikirimkan setiap 3 jam sekali untuk menghemat biaya pengukuran. Walaupun data yang masuk tidak berurutan, namun di dalam database data dikelola menggunakan sistem relational untuk mempermudah penelusuran data.

KLHK1 $|11 / 01 / 2016| 05: 00: 00|28,60| 16,8|0,1| 0,00 \mid$ $3,03|7,38| 111,6|0,0| 0,2|0,33| 69,90|274,00|$ KLHK2 |11/01/2016|06:00:00|28,50|16,9|0,1|0,00| $2,69|7,40| 104,0|0,0| 0,2|0,33| 97,60|265,00|$ KLHK4|11/01/2016|07:00:00|28,30|17,2|0,1|0,00| $1,95|7,41| 105,7|0,1| 0,3|0,34| 23,90|256,00|$ KLHK5 $|11 / 01 / 2016| 05: 00: 00|24,40| 10,4|0,2| 0,00 \mid$ $4,06|2,08| 65,1|0,0| 0,0|0,00| 0,00|65,64|$ KLHK6|11/01/2016|06:00:00|24,30|10,3|0,0| $0,00|3,04| 3,94|61,8| 0,0|0,0| 0,00|0,00| 618,00 \mid$

Gambar 12 berikut adalah contoh grafik hasil pemantauan kualitas air untuk beberapa parameter di kelima lokasi pemantauan di Sungai Ciliwung dan Sungai Cisadane. Grafik di bawah ini menunjukkan hasil pengukuran di Stasiun Masjid Istiqlal di Sungai Ciliwung. Pada awal Januari 2016 hasil pengukuran Turbidity menunjukkan angka 15 NTU dan semakin menurun sampai pada akhir bulan Januari, sedangkan hasil pengukuran parameter TDS menunjukkan angka yang stabil dengan rata-rata $0,5 \mathrm{~g} / \mathrm{l}$.

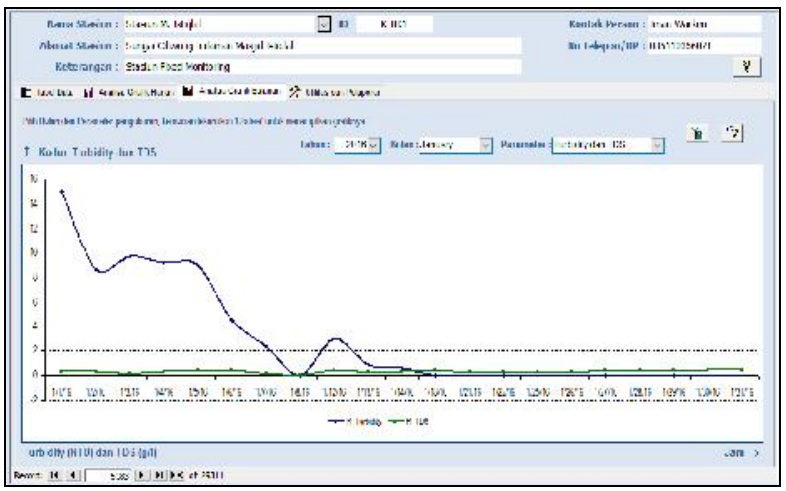

Gambar 12 : Grafik Turbidity dan TDS Pada Bulan Januari 2016 di Stasiun Mesjid Istiqlal Sungai Ciliwung

Grafik di bawah ini menunjukkan hasil pengukuran di Stasiun Manggarai di Sungai Ciliwung.
Pada bulan Januari 2016 hasil pengukuran DO stabil di angka rata-rata $0,17 \mathrm{mg} / \mathrm{l}$ yang berarti kualitas air yang buruk, sedangkan $\mathrm{pH}$ menunjukkan rata-rata di angka 6,4 yang berarti kualitas air yang baik.

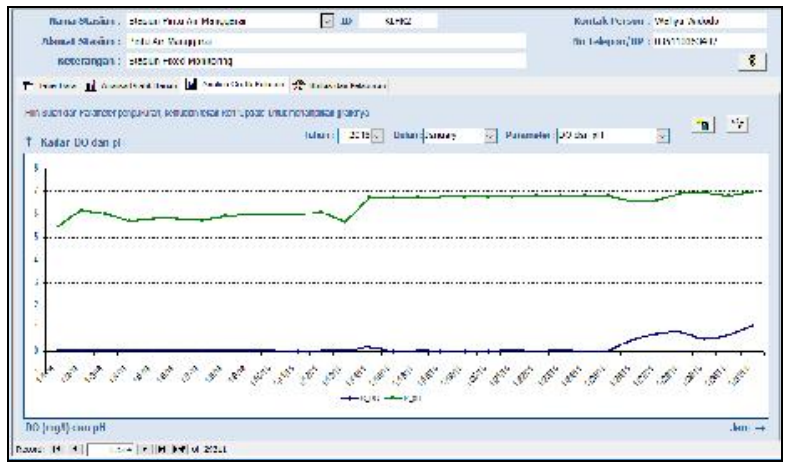

Gambar 13 : Grafik DO dan pH Pada Bulan Januari 2016 di Stasiun Manggarai Sungai Ciliwung

Gambar 14 di bawah ini adalah hasil pengukuran di Stasiun Kelapa Dua di Sungai Ciliwung untuk parameter $\mathrm{pH}$ menunjukkan angka rata-rata 6,97 yang berarti kualitas air yang baik dan parameter Suhu menunjukkan angka rata-rata $28,14{ }^{\circ} \mathrm{C}$.

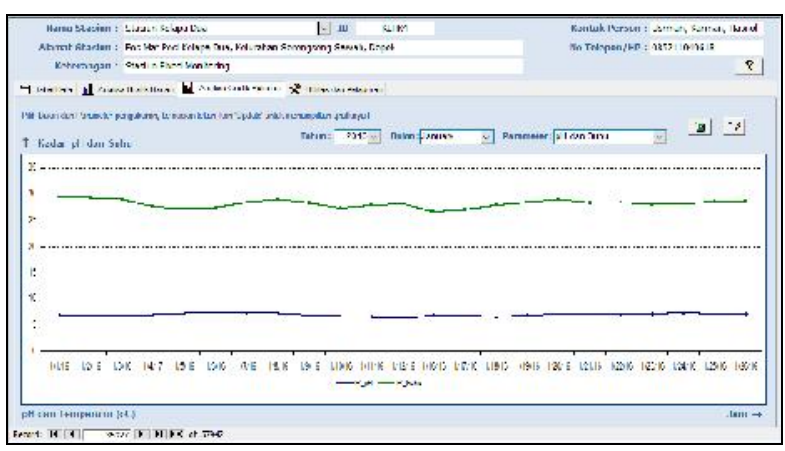

Gambar 14 : Grafik pH dan Suhu Pada Bulan Januari 2016 di Stasiun Kelapa Dua Sungai Ciliwung

Gambar 15 di bawah ini adalah hasil pengukuran di Stasiun Bendung Empang di Sungai Cisadane bagian hulu untuk parameter Nitrat yang menunjukkan fluktuasi yang meningkat untuk beberapa hari di bulan Januari dengan rata-rata hasil pengukurannya adalah $3.425 \mathrm{mg} / \mathrm{l}$.

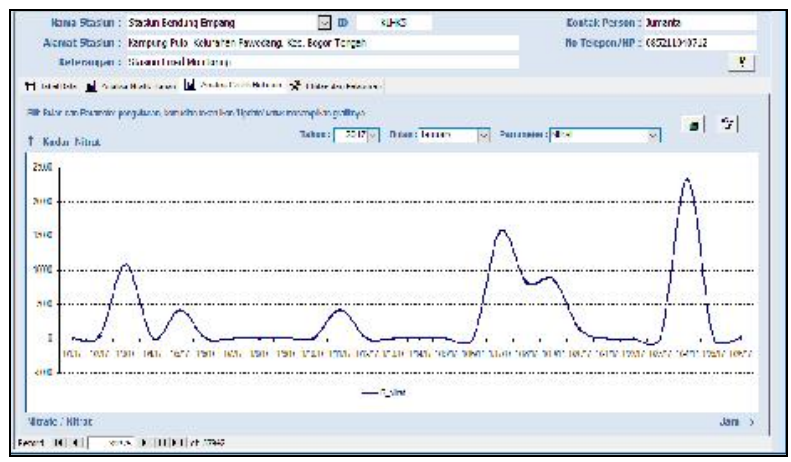

Gambar 15 : Grafik Nitrat Pada Bulan Januari 2016 di Stasiun Bendung Empang Sungai Cisadane 
Gambar 16 di bawah ini adalah hasil pengukuran di Stasiun Bendung Pasar Baru di Sungai Cisadane Hilir untuk parameter amonia yang menunjukkan fluktuasi yang semakin meningkat pada akhir Januari dengan rata-rata hasil pengukurannya adalah $0.03 \mathrm{mg} / \mathrm{l}$.

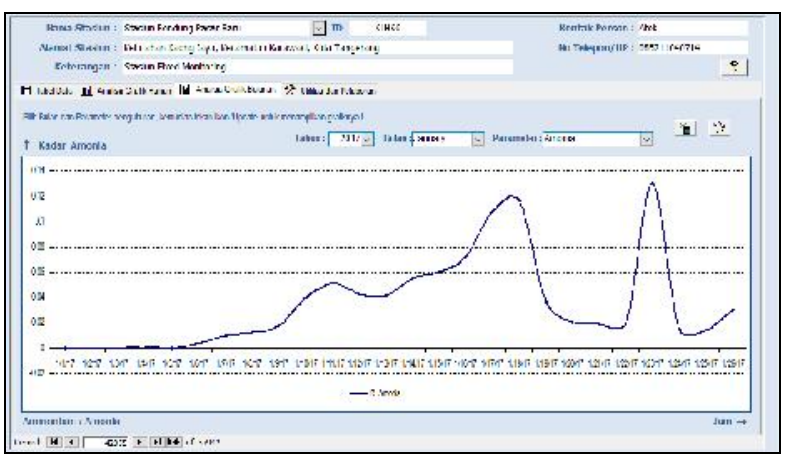

Gambar 16 : Grafik Amonia Pada Bulan Januari 2016 di Stasiun Bendung Pasar Baru Sungai Cisadane

Hasil pengukuran pada gambar-gambar di atas diperoleh dari aplikasi database online monitoring yang dapat mengolah data dan menyajikan data kualitas air dalam bentuk angka maupun grafik.

\subsection{Permasalahan dan Kendala di Lapangan}

Kualitas air sungai-sungai di Indonesia yang mengandung sedimen yang tinggi memberikan dampak kepada menurunnya kualitas air sungai tersebut, ditambah dengan kondisi sampah dan limbah domestik yang terbawa oleh aliran air sungai menyebabkan makin buruknya kondisi sungai. Gambar 17 dan 18 berikut adalah kondisi lokasi intake sistem pompa dan kondisi sensor yang tertutup oleh lumpur.

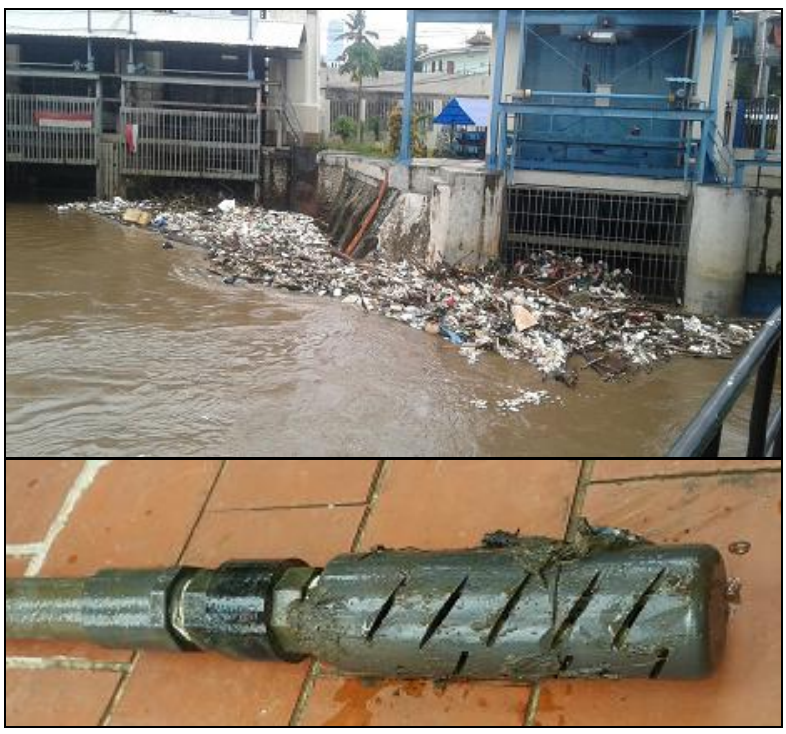

Gambar 17 : Sampah dan Limbah Domestik Yang Mengotori Intake Pompa di Sungai Ciliwung
Multi probe sensor yang bertugas mengukur kualitas air sungai akan mangalami penurunan kinerja pengukuran nya, sehingga frekwensi perawatan harus semakin sering dilakukan pembersihan dan kalibrasi sensor.

Kondisi sampah domestik akan lebih banyak saat musim hujan. Sampah ini dapat menyebabkan rusaknya pipa intake dan bahkan dapat membuat pipa intake hanyut terbawa aliran air. Lumpur yang dibawa oleh aliran air sungai terutama di bagian bawah dasar sungai menyebabkan tertutupnya filter stainer pipa intake sehingga air sungai sulit dipompa ke dalam tangki air di dalam bangunan pelindung. Jika saringan strainer diperbesar lubangnya, maka sebagian lumpur akan ikut terhisap ke dalam tangki air, sehingga dapat mengotori sensor kualitas air di dalam tangki air.

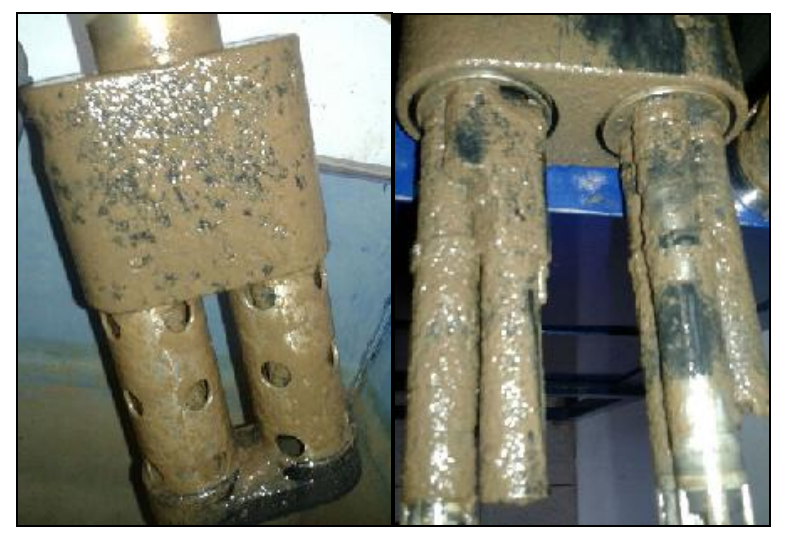

Gambar 18 : Kondisi Sensor Yang Kotor Tertutup Oleh Lumpur

Permasalahan lainnya di lapangan adalah masuknya serangga ke dalam bangunan pelindung yang membuat sarang di dalam box panel RTU atau peralatan lainnya. Gambar berikut ini adalah box panel yang menjadi sarang semut dan tangki pompa yang menjadi sarang lebah.

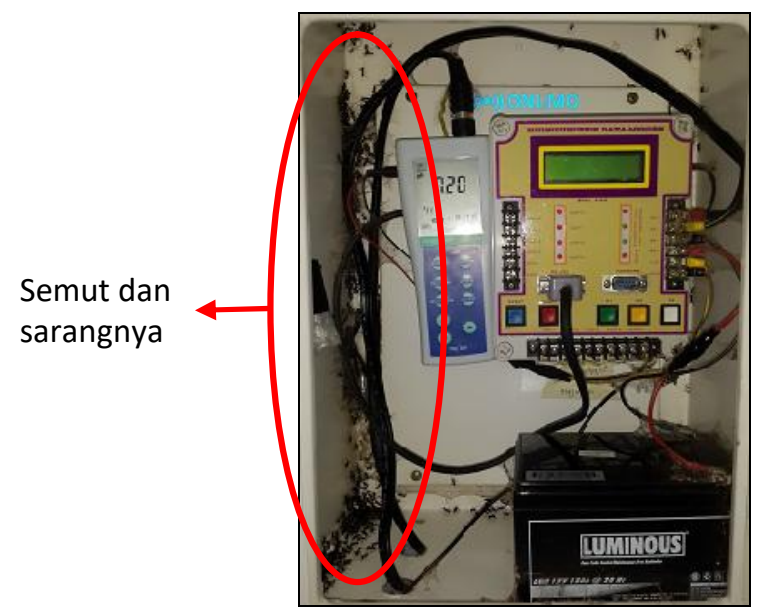

Gambar 19 : Sarang Semut Pada Box Panel RTU dan Terminal Kabel 


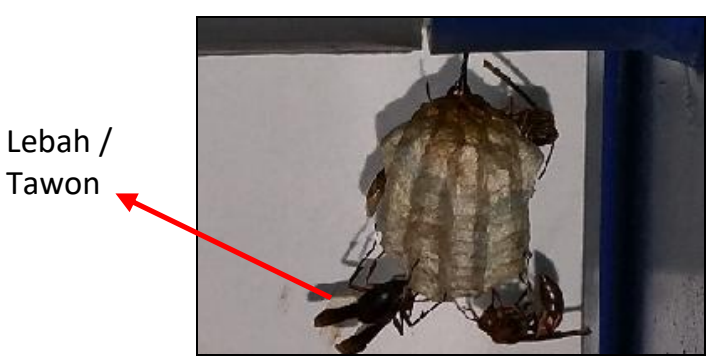

Gambar 20 : Sarang Lebah Pada Pipa Bak Penampungan Air

Permasalahan lainnya di lapangan adalah terkait dengan sistem perpipaan dan pompa yang mengalirkan air sungai ke dalam tangki air di dalam bangunan pelindung. Gambar-gambar berikut ini adalah serangga belalang yang masuk dalam rongga selenoid melalui pipa intake air yang sudah rusak saringan strainernya. Bangkai belalang mengganggu kerja otomatis selenoid sehingga mengeluarkan bunyi yang tidak biasa.

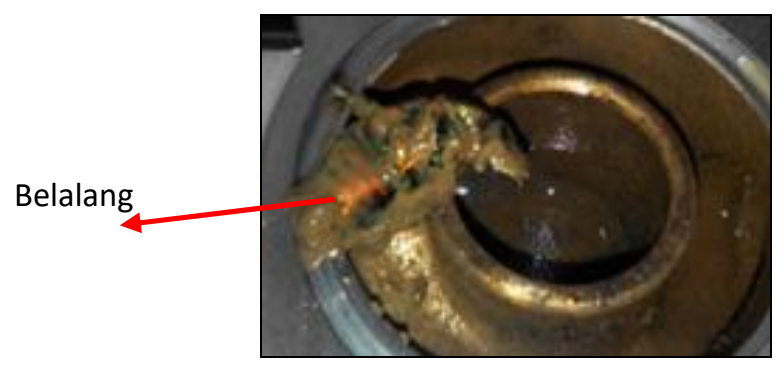

Gambar 21 : Bangkai Belalang Pada Selenoid

Permasalahan-permasalahan di atas dapat diatasi dengan melakukan beberapa inovasi misalnya membuat sistem pembersih sensor dan saringan strainer otomatis, membuat sistem casing box panel yang kedap dari serangga serta memasang saringan udara untuk lubang angin di bangunan pelindung agar serangga tidak masuk.

\section{KESIMPULAN DAN SARAN}

\subsection{Kesimpulan}

Beberapa hal yang dapat disimpulkan dari kegiatan penerapan teknologi online monitoring kualitas air untuk DAS prioritas di Sungai Ciliwung dan Sungai Cisadane adalah sebagai berikut :

- Pemilihan lokasi pemantuan yang disesuaikan dengan ketersediaan anggaran yang dapat digunakan untuk menerapkan teknologi online monitoring di kedua sungai adalah posisi hulu dan hilir sungai.

- Lokasi di Sungai Ciliwung dipilih lokasi yang mewakili bagian hulu, tengah dan hilir Sungai Ciliwung sekaligus mewakili daerah pada penduduk dan kawasan perkantoran.
- Lokasi di Sungai Cisadane dipilih lokasi yang mewakili bagian hulu dan hilir Sungai Cisadane dan diharapkan dapat menunjukkan perbedaan kualitas dari daerah sumber air dan daerah akhir sungai setelah melewati beberapa kawasan industri, perumahan dan perkantoran.

- Pemilihan lokasi di bendung merupakan salah satu kriteria pemilihan lokasi dengan mempertimbangkan keamanan dan kemudahan saat dilakukannya instalasi dan pemeliharaan.

- Pada lokasi pemantauan di Sungai Ciliwung diinstalasikan sistem pengambilan sampling air menggunakan sistem pompa dengan pertimbangan kualitas air di sungai ini yang buruk dan banyak membawa sampah domestik dan lumpur.

- Pada lokasi pemantauan di Sungai Cisadane diinstalasikan sistem pengambilan sampling air dengan mencelupkan sensor secara langsung ke dalam sungai melalui pipa casing dan sistem pengampung sensor dengan pertimbangan bahwa kualitas air di sungai ini relatif lebih bersih dari sampah domestik dan lumpur.

- $\quad$ Sistem kelistrikan solar cell dengan kapasitas batere $12 \mathrm{~V} 12 \mathrm{Ah}$ mampu menyediakan energi listrik pada perangkat data logger selama 24 jam walaupun dalam keadaan mendung atau tertutup awan.

- $\quad$ Sistem kelistrikan untuk sistem pompa yang dioperasikan setiap satu jam sekali selama 10 menit dapat menghemat biaya penggunaan listrik PLN, yang setiap bulannya rata-rata adalah Rp. 60.000,-

- Ketiga aplikasi sistem online monitoring kualitas air yakni SMS gateway, Database Online Monitoring dan Aplikasi Web dapat bekerja dengan baik. Ketiga aplikasi ini dapat melakukan sinkronisasi data melalui penggunaan satu file bersama, yaitu DataPengukuran.txt yang secara rutin terupdate oleh aplikasi SMS Gateway.

- Bangunan pelindung dalam bentuk bangunan sipil beton dapat melindungi seluruh peralatan secara baik dari panas dan hujan. Temperatur di dalam ruangan tidak terlalu panas dengan adanya lubang angin untuk sirkulasi udara.

\subsection{Saran}

Kegiatan penerapan teknologi online monitoring kualitas air di DAS Prioritas merupakan kegiatan yang sudah sesuai dengan tupoksi instansi Kementerian Lingkungan Hidup dan Kehutanan (KLHK) dan sudah ada pada rencana kerja jangka panjangnya. Berdasarkan pengalaman BPPT mendampingi mitra dalam menerapkan teknologi ini, kebanyakan tingkat keberhasilan dan keberlanjutan kegiatan ini sangat 
rendah dikarenakan komitmen mitra yang hanya satu atau dua tahun saja untuk melaksanakan kegiatan ini.

Beberapa rekomendasi dan saran kepada mitra yang dapat disampaikan adalah sebagai berikut :

- Kegiatan penerapan teknologi online monitoring kualitas air yang bertujuan untuk mendukung kegiatan pengendalian pencemaran lingkungan di KLHK perlu mendapatkan dukungan komitmen dari pimpinan instansi untuk keberlanjutan pengoperasian dan perawatan sistem yang telah diinvestasikan.

- Kegiatan penerapan teknologi telemeteri perlu didukung oleh kegiatan kelembagaan yang sejalan dengan tujuan dan sasaran diterapkannya teknologi ini. Jika diprosentasekan bobot kedua kegiatan ini, maka kegiatan pengadaan dan penerapan teknologi telemeteri hanya memiliki bobot $40 \%$ tingkat keberhasilan jika dibandingkan dengan pengembangan kelembagaan untuk teknologi yang memiliki bobot $60 \%$ tingkat keberhasilan.

- Kedua kegiatan ini saling mendukung sehingga dapat tercapai $100 \%$ tingkat keberhasilkan jika kedua kegiatan ini dijalankan secara beriringan dan bersama-sama.

- Beberapa komitmen yang perlu diberikan oleh pimpinan instansi adalah :

$\checkmark$ Pendanaan untuk operasional dan perawatan sistem peralatan.

$\checkmark$ Penyediaan SDM pada unit kerja dalam organisasi yang profesional dan terlatih serta fokus untuk kegiatan pengoperasian dan perawatan peralatan online monitoring ini. Struktur organisasi yang direkomendasikan seperti pada lampiran gambar 22 .

$\checkmark$ Penyusunan sistem kelembagaan yang baik yang mendukung pelaksanaan penerapan teknologi online monitoring kualitas air.

$\checkmark$ Dukungan peraturan perundangan yang mengatur tentang kriteria / petunjuk teknis dalam penerapan teknologi ini.

$\checkmark$ Dukungan peraturan perundangan yang mengatur tentang hasil pemantauan online yang dapat digunakan sebagai bukti terjadinya pencemaran.

$\checkmark$ Dukungan peraturan perundangan yang mengatur tentang tindakan yang harus dilakukan terkait terjadinya pencemaran yang dideteksi oleh sistem peralatan online monitoring kualitas air, misalnya dalam bentuk SOP Tanggap Pencemaran.

- Diperlukan kerjasama antara Kementerian Lingkungan Hidup dan Kehutanan (KLHK) dengan Kementerian Pekerjaan Umum dan Perumahan Rakyat (PUPR) dalam menentukan lokasi pemantauan yang memanfaatkan infrastruktur yang dimiliki oleh PUPR untuk mengurangi biaya investasi bangunan pelindung.

- Perlu dibentuk garis komando birokrasi yang jelas antara KLHK dengan Dinas Lingkungan Hidup dan Kehutanan di daerah dalam menerapkan teknologi online monitoring kualitas air. KLHK sebagai instansi pusat yang mengatur anggaran dan regulasi dalam penerapan teknologi ini, sedangkan DLHK di daerah yang menjalankan dan mengoperasikannya.

- Untuk menjamin kualitas data perlu dilakukan penggantian probe sensor untuk parameter pengukuran $\mathrm{pH}, \mathrm{DO}$, amonia dan nitrat minimal satu kali dalam enam bulan.

- Selain itu juga perlu disusun metoda penjaminan kualitas data terhadap data anomali yang mungkin akan terkirim akibat penurunan kinerja multiprobe sensor.

- Untuk memperpanjang jangka waktu perawatan sensor, perlu dilakukan inovasi sistem pembersih sensor secara otomatis yang dapat bekerja hanya dengan menggunakan solar cell dan air sungai yang ada untuk membersihkan sensor.

- Untuk menghemat biaya operasional pompa juga perlu dilakukan inovasi sistem kelistrikan pompa yang menggunakan solar cell.

\section{UCAPAN TERIMAKASIH}

Ucapan terimakasih ditujukan kepada seluruh Ditjen PPKL Kementerian Lingkungan Hidup dan Kehutanan yang telah memberikan kepercayaan kepada BPPT dalam melaksanakan kegiatan penerapan teknologi monitoring di Indonesia. Tak lupa ucapan terimakasih juga ditujukan kepada seluruh anggota tim pengembang Onlimo di Pusat Teknologi Lingkungan, BPPT yang telah bekerja keras melaksanakan pengkajian dan penerapan teknologi online monitoring kualitas air.

\section{DAFTAR PUSTAKA}

- Tempo.CO, "Sebanyak 73 Persen Sungai Di Indonesia Tercemar", 4 mei 2015, Situs Tempo,.

- Wikipedia, Ensiklopedia Bebas, http:// http://id.wikipedia.org/wiki/Ci_Liwung \& http:// http://id.wikipedia.org/wiki/Ci_Sadane, 2016

- Heru Dwi Wahjono, Sistem Pemantauan Online Untuk Pengendalian Pencemaran Kualitas Air di DAS Ciliwung, PTL - BPPT, 2015

- Bayu Budiman dan Heru Dwi Wahjono, Petunjuk Operasional Sistem Online Monitoring Kualitas Air Berbasis SMS, Pusat Teknonologi Lingkungan BPPT, 2013

- TOA-DKK Corporation, Dokumen Teknis, Water Quality Meter Model WQC-24, 2015 
- Heru Dwi Wahjono, Petunjuk Operasional Software Database Online Monitoring Kualitas Air di Danau Semayang \& Melintang, Pusat Teknologi Lingkungan - BPPT, 2013
- $\quad$ BPPT Enjiniring, Dokumen Teknis, Laporan Akhir Pemasangan Alat Online Monitoring Sistem di Ciliwung dan Citarum, 2015 


\section{LAMPIRAN}

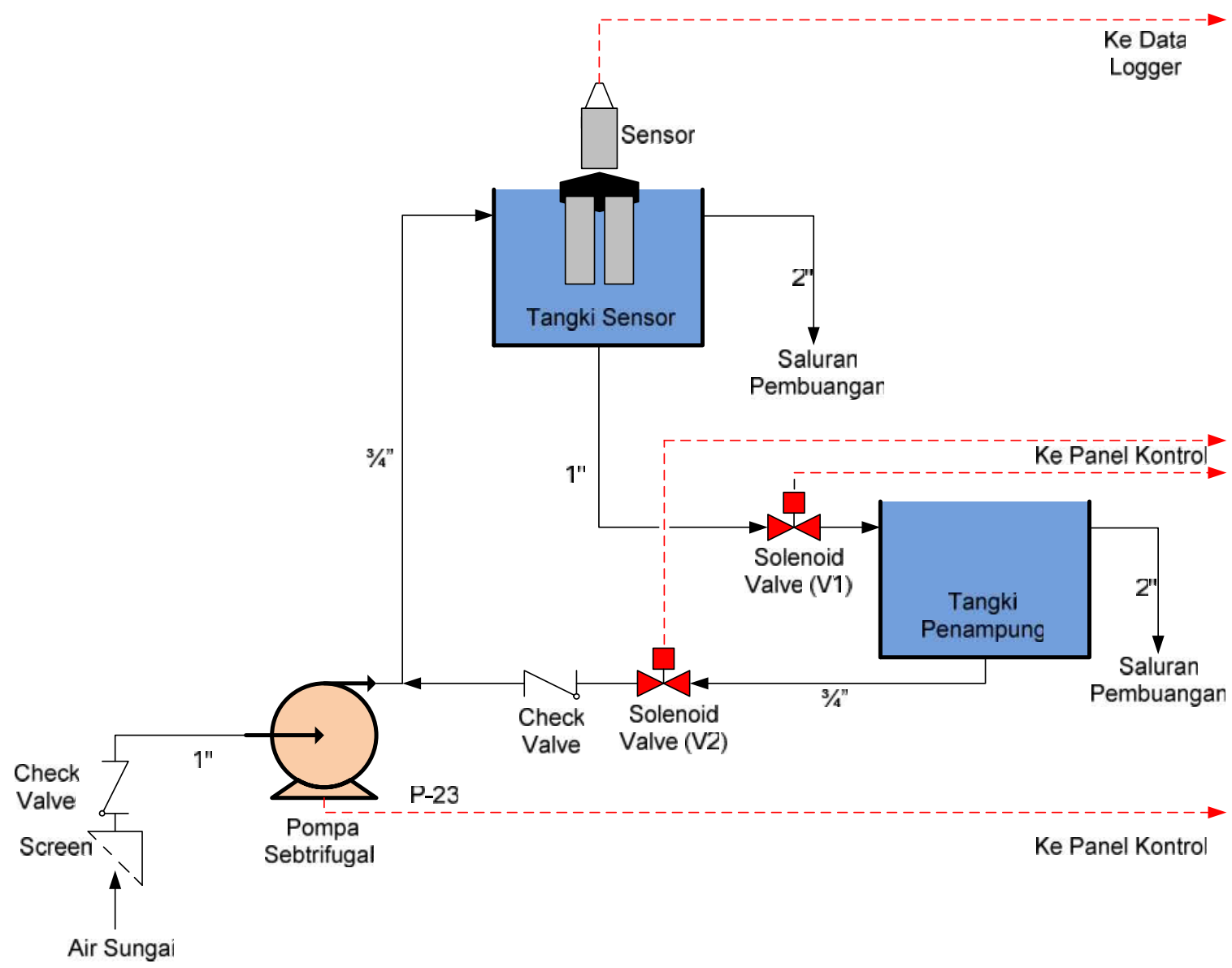

Gambar 22 : Diagram Sistem Pemompaan

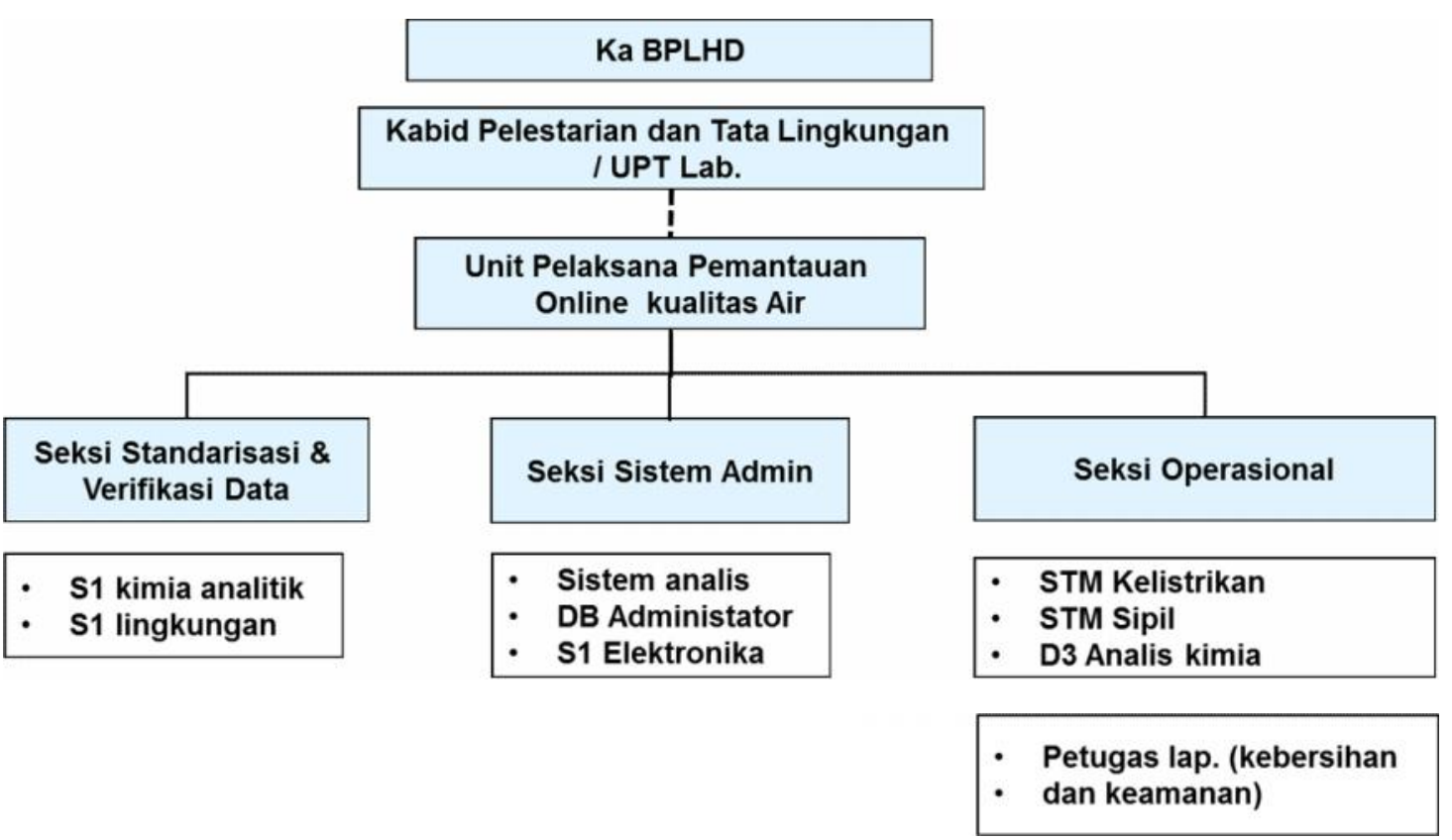

Gambar 23 : Struktur Organisasi Pengelola Sistem Online Monitoring 


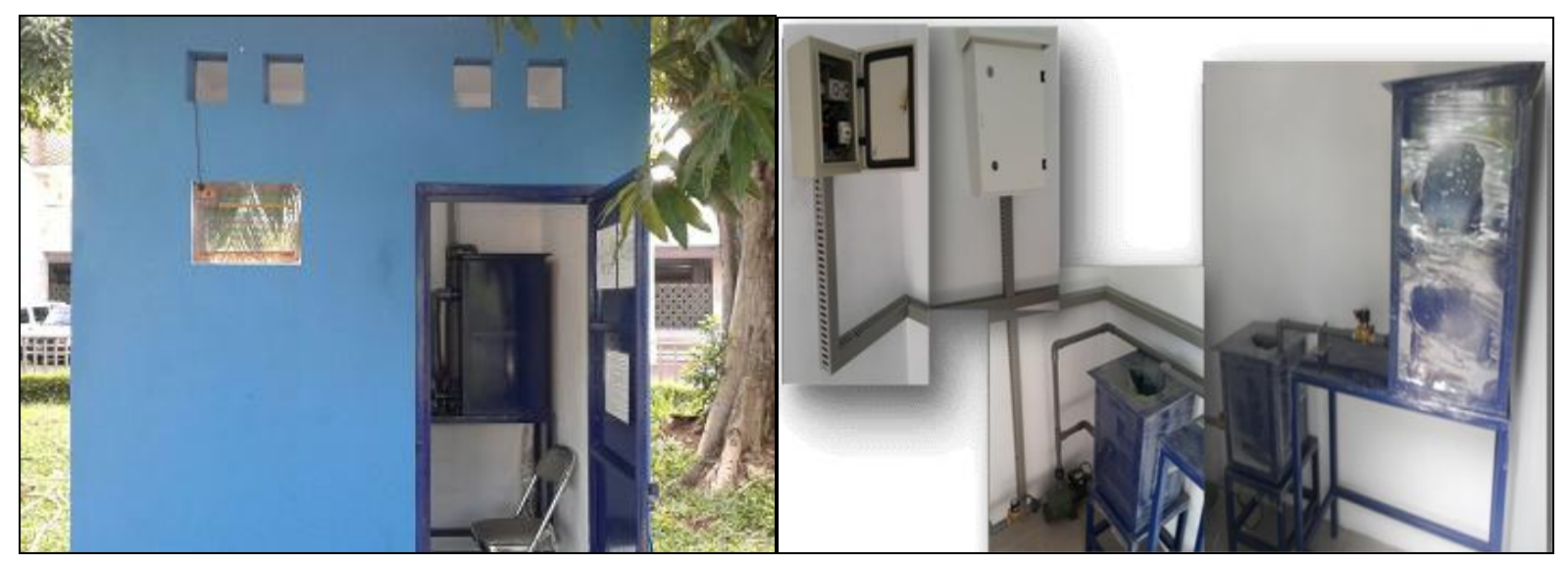

Gambar 24 : STO Masjid Istiqlal (S. Ciliwung Hilir, Jakarta Pusat)

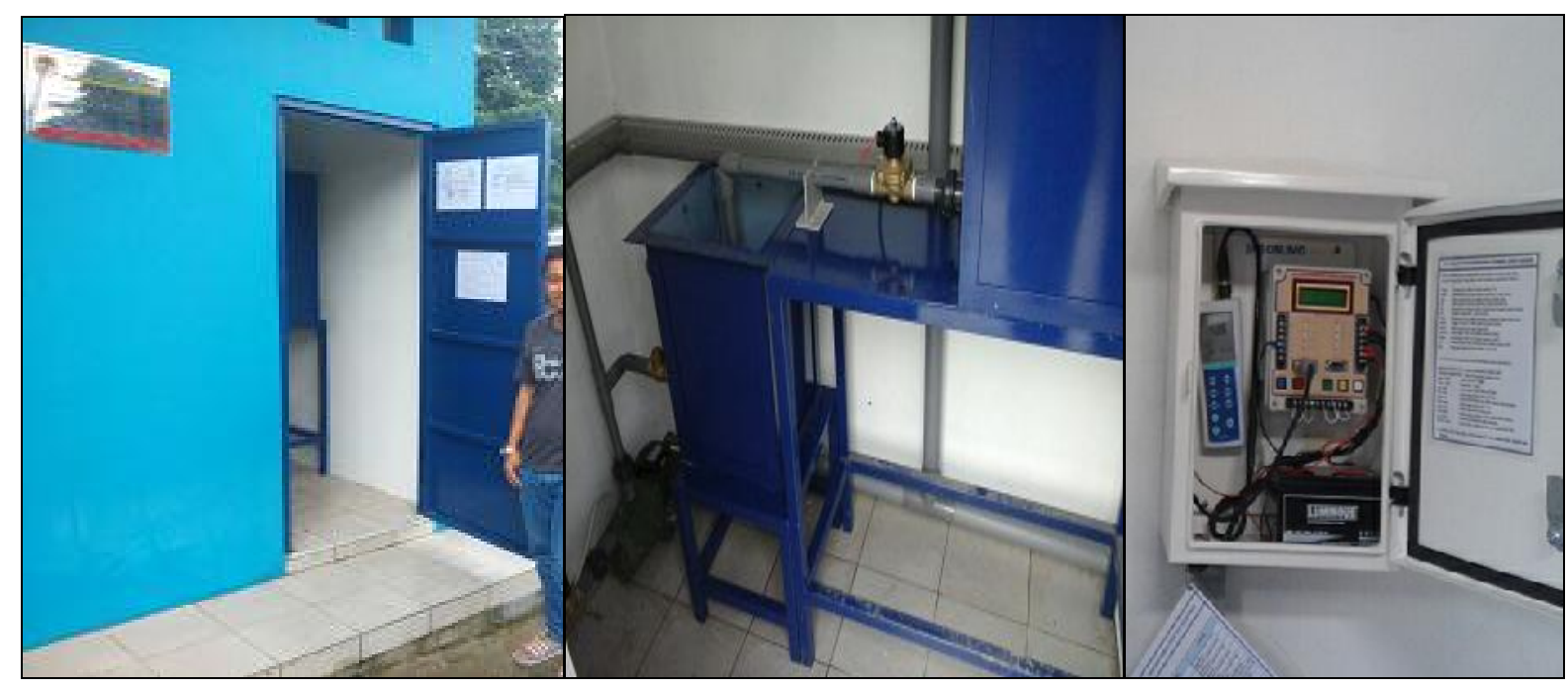

Gambar 25 : STO Manggarai (S. Ciliwung Tengah, Jakarta Selatan)

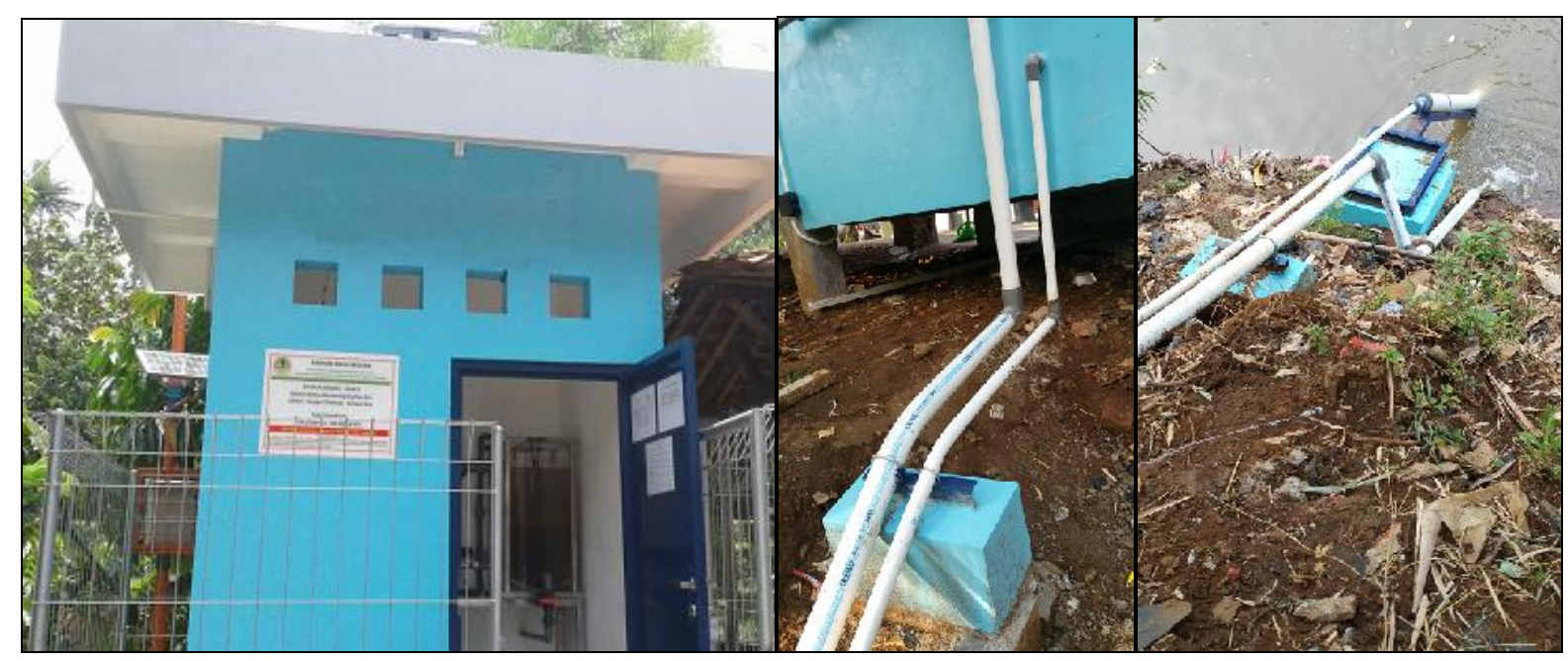

Gambar 26 : STO Kelapa Dua (S. Ciliwung Hulu, Depok) 


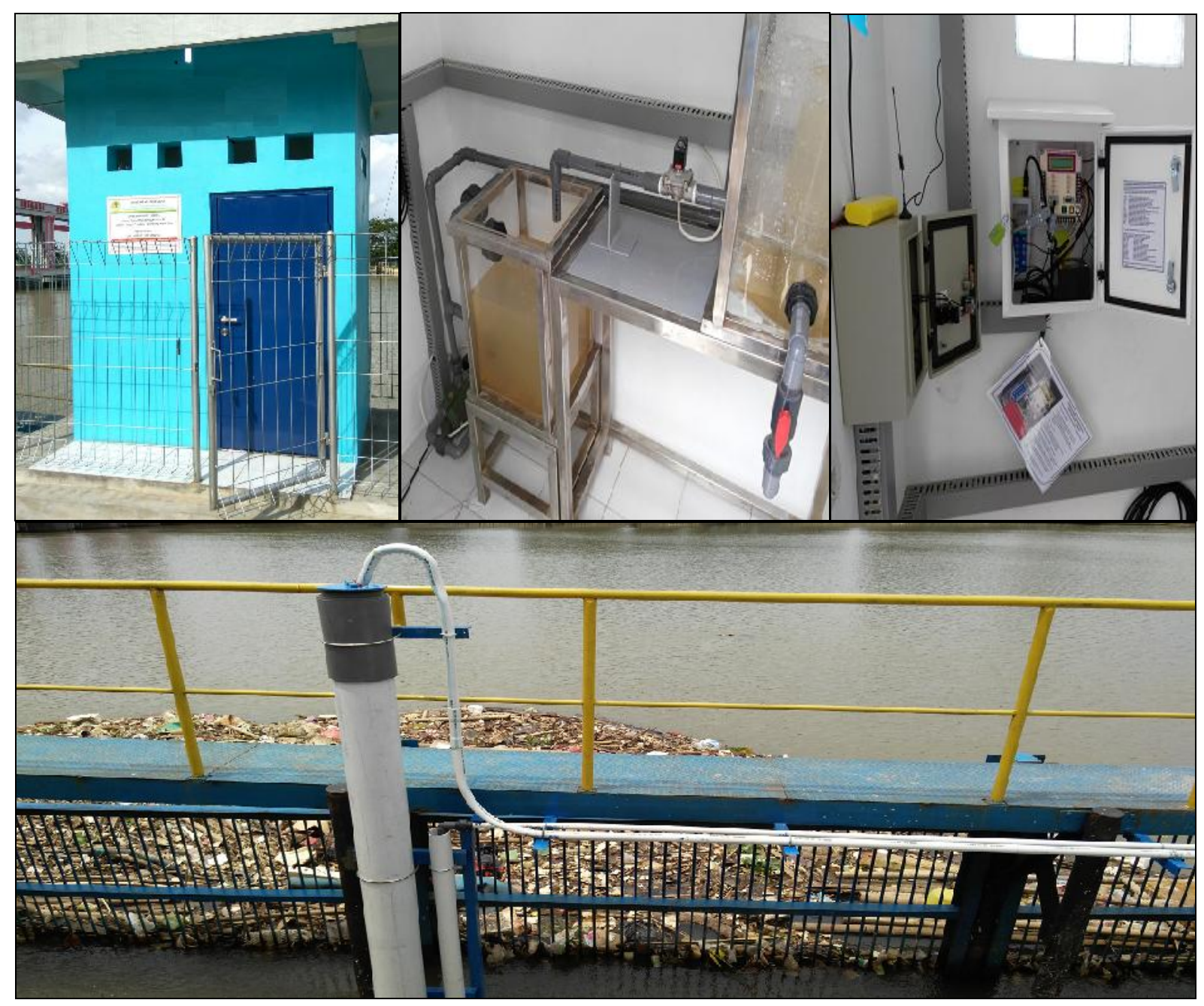

Gambar 26 : STO Bendung Pasar Baru (S. Cisadane Hilir, Tangerang)

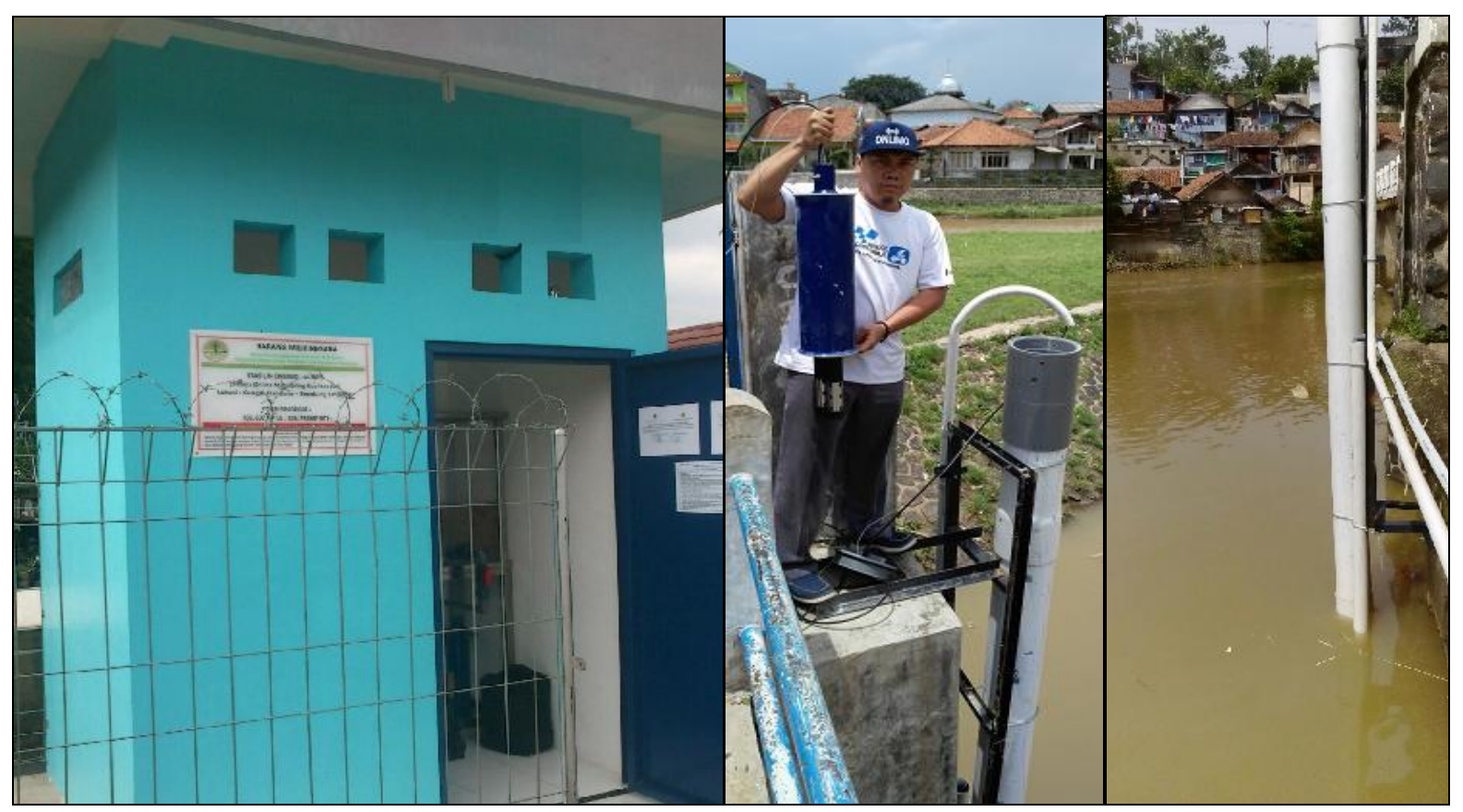

Gambar 27 : STO Bendung Empang (S. Cisadane Hulu, Bogor) 